\title{
HODGKIN'S DISEASE - RECENT DEVELOPMENTS
}

\author{
Major R.' L. WARKEL, M.D., M.C. (U.S.A.) * \\ Lieutenant-Colonel J. B. STEWART \\ M.B., M.R.C.Path., D.R.C.Path., D.T.M.\&H., R.A.M.C. \\ Royal Army Medical College, Millbank
}

\section{Introduction}

MORE than one and a half centuries after Thomas Hodgkin's publication (Hodgkin 1832), the nature of Hodgkin's disease remains a mystery. The relentless search for clues to our understanding of the disease continues at a fervid pace and particularly in the last decade there have been so many developments of a complex and, at times, seemingly mutually contradictory nature that they have been collectively labelled a " maze" (Lancet editorial 1969, 1971). It is the purpose of this paper to review some of these developments, emphasising the histological aspects in conjunction with some of our own impressions based on a preliminary histopathological analysis of material from 90 untreated patients submitted to the Army Histopathology Registry (AHR) during the years $1965-1973$.

\section{Aetiology}

Epidemiology. While generally accepted as a malignant tumour, Hodgkin's disease presents both clinical and histological features that suggest a possible association or inter-relationship with an infectious agent. MacMahon $(1957,1966)$ on the basis of epidemiological factors hypothesised that Hodgkin's disease may be basically two entities rather than one. He found that there was a bimodal age distribution curve with peaks in the 15-34 age group and in the over 50 group. The younger patients have less male predominance, a more favourable histology and a better prognosis than the older group (Newell et al 1970). MacMahon (1966) suggested that Hodgkin's disease in the young was a granulomatous inflammation and in older adults was a true neoplasm comparable to other lymphomas. Additional epidemiological factors interpreted as supporting the dual entity concept include international variations in disease frequency (MacMahon 1966) and the study of Cole, MacMahon and Aisenberg (1968) showing that the mortality from Hodgkin's disease in eleven Southern States of the United States was only half that of the remainder of the country in the younger age group, while being virtually identical for the middle-aged and elderly. Smithers (1970) was unconvinced and considered Hodgkin's disease a single progressive malignancy, attributing the observed differences in survival and in incidence to environmental and host factors. Evidence favouring the concept of heterogeneity comes from studies at the molecular level where the activities of deoxyribonucleic acid (DNA) dependent DNA polymerase in tissues from patients with nodular sclerosing Hodgkin's disease were found to differ from those with mixed cellularity type (Piperno and Kallen 1973).

Support for a possible relationship to infection is derived from the finding that cases of Hodgkin's disease appear to occur in clusters. Vianna et al (1972) found an extended epidemic with 34 cases of lymphoma, of which 31 were Hodgkin's disease,

* Exchange Officer, Armed Forces Institute of Pathology, Washington, D.C., U.S.A. 
occurring over two decades centred around a certain High School in Albany, New York. These cases, of which only two were familial, could all be linked either directly or through a contact. These findings were interpreted as suggesting an infectious disease with a carrier state and a long incubation period. In another study from a different part of New York, Vianna and Polan (1973) found that schools having one case of Hodgkin's disease subsequently developed more than the expected number of cases in pupils or teachers attending the same school.

Viruses. Speculation on the possibility of a viral determinant in Hodgkin's disease has focused primarily on the Epstein-Barr virus (EBV), a member of the herpesvirus group. The EBV was first detected in cultured lymphoblasts from Burkitt's African lymphoma (Epstein, Achong and Barr 1964). Epidemiological and immunological findings support the contention that EBV is the aetiological agent of infectious mononucleosis (Niederman et al 1968). The laboratory evidence linking it to Hodgkin's disease is not conclusive. Johansson et al (1970) and Levine et al (1971) found elevated antibody titres to EBV in patient's serum. However, Goldman and Aisenberg (1970) could find no significant difference in antibody titres between patients with Hodgkin's disease and age-matched controls. Eisenger et al (1971) working with long term cell cultures of lymph nodes from patients with Hodgkin's disease observed the emergence of an agent that was tentatively identified as a member of the herpes group, although not EBV.

The possibility of an association between EBV and Hodgkin's disease is intriguing in view of the association of EBV with Burkitt's lymphoma and infectious mononucleosis. Reed-Sternberg cells, once considered specific for Hodgkin's disease, have been seen in both Burkitt's lymphoma (Wright 1970) and in infectious mononucleosis (Lukes, Tindle and Parker 1969). A prevailing theory is that Burkitt's lymphoma is initiated by EBV after priming by malarial infection (Burkitt 1969). A possible analogous association between infectious mononucleosis and Hodgkin's disease is suggested by the frequently obtained history of prior infectious mononucleosis among patients with Hodgkin's disease (Kaplan 1971).

Tonsillectomy. Conflicting reports exist on the relationship between tonsillectomy and Hodgkin's disease. Johnson and Johnson (1972) and Ruuskanen, Vanha-Perttula and Kouvalainen (1971) claimed there was no correlation, but Vianna, Greenwald and Davies (1971) found a significant increase in history of prior tonsillectomy in patient's with Hodgkin's disease as compared to controls. (Table I). The explanation proposed by Vianna et al (1971) was that tonsillectomy perhaps removes a protective barrier to the Hodgkin's disease agent.

Table I

Proportion of patients with tonsillectomies

\begin{tabular}{|c|c|c|c|c|}
\hline \multirow[b]{2}{*}{ Series } & \multicolumn{2}{|c|}{ Hodgkin's patients } & \multicolumn{2}{|c|}{ Controls } \\
\hline & Proportion & Per cent & Proportion & Per cent \\
\hline $\begin{array}{l}\text { Vianna et al (1971) } \\
\text { Ruuskanen, Vanha-Perttula and } \\
\quad \text { Kouvalainen (1971) } \\
\text { Johnson and Johnson (1972) }\end{array}$ & $\begin{array}{r}67 / 109 \\
5 / 53 \\
41 / 85\end{array}$ & $\begin{array}{l}61 \\
9.4 \\
48\end{array}$ & $\begin{array}{c}43 / 109 \\
7 / 53 \\
33 / 85\end{array}$ & $\begin{array}{l}39 \\
13 \\
39\end{array}$ \\
\hline
\end{tabular}


Leucocyte antigens. Evidence of an inherited susceptibility to Hodgkin's disease is provided by the finding of an increased incidence of human leucocyte antigens (HLA) belonging to the 4C system in patients with Hodgkin's disease (Forbes and Morris 1970, Bertrams et al 1972). In experimental animals the capacity to react immunologically to certain antigens and the susceptibility to certain leukaemogenic viruses is associated with their major histocompatibility system (Martin et al 1970, Lilly 1964). These findings suggest that a similar relationship between histocompatibility genes, immunological responsiveness and oncogenic viruses may exist in man.

\section{Immunology}

Patients with Hodgkin's disease have a defect in cell-mediated immunity, the T-cell (thymus dependent) division of the lymphoid system, that appears earlier in the disease as compared with other neoplasms (Aisenberg 1966) and is manifested by a failure to respond to a battery of skin allergens (Schier et al 1956), an inability to acquire contact sensitivity to dinitrochlorobenzene (Aisenberg 1962), a decreased rejection of skin allografts (Miller, Lizardo and Snyderman 1961) and a reduced peripheral blood lymphocyte response to phytohaemagglutinin (Hersh and Oppenheim 1965). Impairment of cellular immunity varies with the clinical stage of the disease (Brown et al 1967; Young et al 1972). It is usually normal in Stage I and decreased in the more advanced stages, although in one study (Young et al 1972) only 27 per cent of untreated patients with Stage IV disease were anergic. Humoral antibody production, a B-cell (bonemarrow dependent) function usually remains intact until the terminal phases of the disease (Aisenberg 1966, Brown et al 1967).

A theory relating host immunity to viral infection has been postulated by Order and Hellman (1972). They suggested that T-cells may become infected by a tumourinducing virus thereby causing a change in cell-surface antigens to which normal immunocompetent host $\mathrm{T}$-cells then react. This interaction could then lead in a manner analogous to that of a chronic graft-versus-host reaction to the production of neoplasia. The appearance of malignant lymphomas has been described in chronic graft-versushost disease in mice (Schwartz and Andre-Schwartz 1968).

Longmire et al (1973) detected elevated levels of immunoglobin G (IgG) production by spleens from patients with Hodgkin's disease as compared to controls. Binding of splenic IgG to homologous lymphocytes suggested that the IgG produced in Hodgkin's disease is specific for, or is cross-reacting with, antigenic sites on lymphocytes. Based on these observations and the frequent occurrence of reactive lymphoid enlargement without tumour involvement in known cases De Vita (1973) envisioned " a lymphocyte civil war" transpiring in Hodgkin's disease. He postulated that T lymphocytes are malignantly transformed and antigenically altered perhaps by a virus. B-cells then produce antibodies to the malignant $\mathrm{T}$-cells with cross-specificity to non-malignant T-cells. This theory could explain the early and progressive impairment of cell-mediated immunity, the increased splenic IgG production and the sometimes encountered autoimmune phenomena.

\section{Histology}

Diagnosis. Hodgkin's disease can only be confirmed by microscopic examination of an adequate and properly prepared biopsy by an experienced histopathologist. The 
difficulty of this task was emphasised by Symmers (1968) when he showed a 47 per cent error in a review of cases of lymphadenopathy originally diagnosed as Hodgkin's disease. The histological diagnosis depends on the demonstration of Reed-Sternberg cells in an appropriate cellular background.

The classical Reed-Sternberg cell as seen in the haematoxylin and eosin stain is a large reticulum cell measuring approximately $15-45$ microns in diameter (Fig. 1). It is

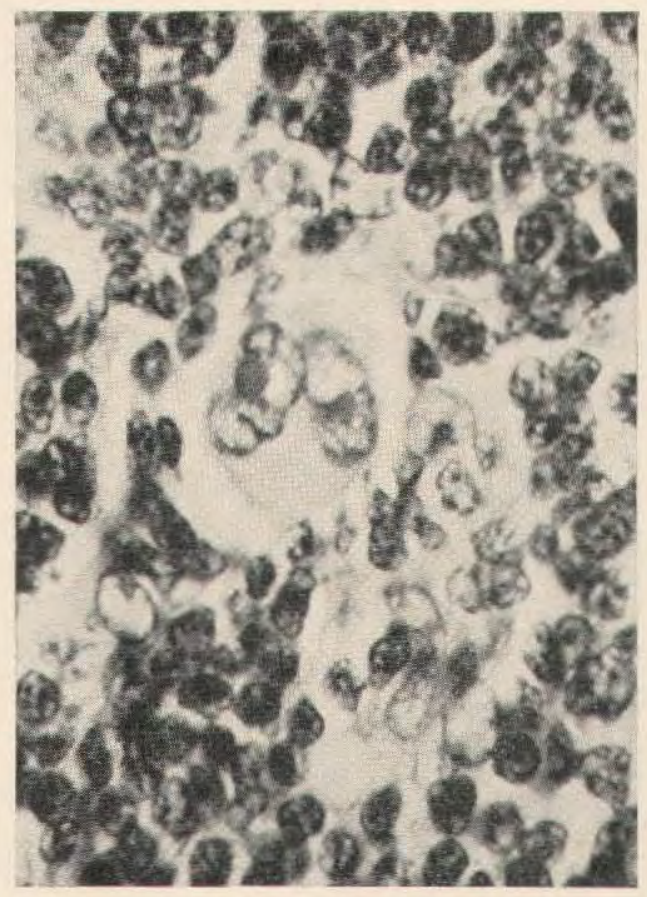

Fig. 1.

Reed-Sternberg cell. The large cell in the centre contains two nuclei, each of which have large prominent nucleoli $(\mathrm{H}$ and $\mathrm{E}, \mathrm{x} 650)$.

either multinucleated or multilobulated with a pale amphophilic or eosinophilic cytoplasm. Each nucleus or nuclear lobe contains a single large magenta nucleolus. The area between the nucleolus and the nuclear membrane is usually clear although in some cells slender strands of chromatin may be seen radiating from the nucleolus. Although a prerequisite for the diagnosis of Hodgkin's disease, Reed-Sternberg cells are not pathognomonic. Virtually identical cells have been seen in a variety of benign and malignant conditions, including infectious mononucleosis (Lukes, Tindle and Parker 1969), Burkitt's lymphoma (Wright 1970), postvaccinial lymphadenitis (Hartsock 1968), lymphocytic lymphoma (Schnitzer 1970), malignant melanoma and carcinoma of the breast (Strum, Park and Rappaport 1970). The lack of an appropriate cellular milieu distinguishes these entities from Hodgkin's disease.

Classification. The second requirement for the histological diagnosis of Hodgkin's disease is an appropriate cellular and architectural environment. It is this environment that forms the basis of the histological classification. Hodgkin's disease is unique among neoplasms in that it is classified on the basis of the inflammatory response that it engenders and not by the intrinsic features of the neoplastic cells. 
Until 1965 the histologic classification routinely used by most pathologists was that of Jackson and Parker (1944). The three sub-divisions of this classification in descending order of association with survival were: paragranuloma, granuloma and sarcoma. The abandonment of this classification was necessitated by the finding that $80-90$ per cent of the cases of Hodgkin's disease fell into the granuloma subgroups. At the Army Histopathology Registry the Rye Conference modification (Lukes et al 1966c) of the classification of Lukes and Butler (1966a) is used. Another classification has been proposed by Cross (1969), but this has not enjoyed much worldwide acceptance.

An outline of the features of the four histologic types of the Rye Conference classification is presented in Table II and depicted in Figs 2 to 7 . With the exception of

Table $\Pi$

Rye Conference classification (Lukes et al 1966c) as interpreted by the Army Histopathology Registry

\begin{tabular}{|c|c|c|}
\hline Histological type & $\begin{array}{l}\text { Features essential for } \\
\text { diagnosis }\end{array}$ & $\begin{array}{l}\text { Additional features not } \\
\text { essential for diagnosis }\end{array}$ \\
\hline Lymphocyte predominance & $\begin{array}{l}\text { 1. Predominance of } \\
\text { lymphocytes } \\
\text { 2. Few Reed-Sternberg and } \\
\text { atypical reticulum } \\
\text { cells }\end{array}$ & $\begin{array}{l}\text { 1. Variable number of benign } \\
\text { histiocytes }\end{array}$ \\
\hline Nodular sclerosis & $\begin{array}{l}\text { 1. Nodules formed by broad } \\
\text { birefringent collagenous } \\
\text { bands and/or } \\
\text { 2. Lacunar cells } \\
\text { 3. Reed-Sternberg cells }\end{array}$ & $\begin{array}{l}\text { 1. Cellular composition that } \\
\text { of any of the other histologic } \\
\text { types }\end{array}$ \\
\hline Mixed cellularity & $\begin{array}{l}\text { 1. Moderate numbers of } \\
\text { lymphocytes } \\
\text { 2. Moderate numbers of } \\
\text { Reed-Sternberg and } \\
\text { atypical reticulum } \\
\text { cells }\end{array}$ & $\begin{array}{l}\text { 1. Many eosinophils, plasma } \\
\text { cells, neutrophils or } \\
\text { histiocytes } \\
\text { 2. Mild disorderly fibrosis } \\
\text { 3. Necrosis occasionally } \\
\text { present }\end{array}$ \\
\hline Lymphocyte depletion & $\begin{array}{l}\text { 1. Numerous Reed-Sternberg } \\
\text { cells and/or atypical } \\
\text { reticulum cells } \\
\text { 2. Few lymphocytes }\end{array}$ & $\begin{array}{l}\text { 1. Marked disorderly } \\
\text { fibrosis * } \\
\text { 2. Pleomorphism, of reticulum } \\
\text { cells } \\
\text { 3. Necrosis often present }\end{array}$ \\
\hline
\end{tabular}

* Diffuse fibrosis type and $\uparrow$ Reticular type in classification of Lukes and Butler (1966a).

nodular sclerosis (NS) the classification is based on the relative proportion of lymphocytes to atypical reticulum cells. Reed-Sternberg cells are difficult to find in the lymphocytic predominant (LP) type, whereas generally they are plentiful in lymphocytic depletion (LD), except when diffuse fibrosis has replaced most of the cellularity. Intermediate numbers are found in mixed cellularity (MC), the group to which any lesion is ascribed that fails to display ingredients of the other types. Connective tissue proliferation is a feature of both nodular sclerosis and the diffuse fibrosis variant of lymphocytic depletion. In lymphocytic depletion the fibrosis is disorderly, non-birefringent and composed of amorphous material resembling pre-collagen. The fibrous tissue in nodular sclerosis forms thick bands with a regular arrangement and strong birefringence under polarized light. Rappaport et al $(1971 \mathrm{~b})$ have recommended that when only a portion of 


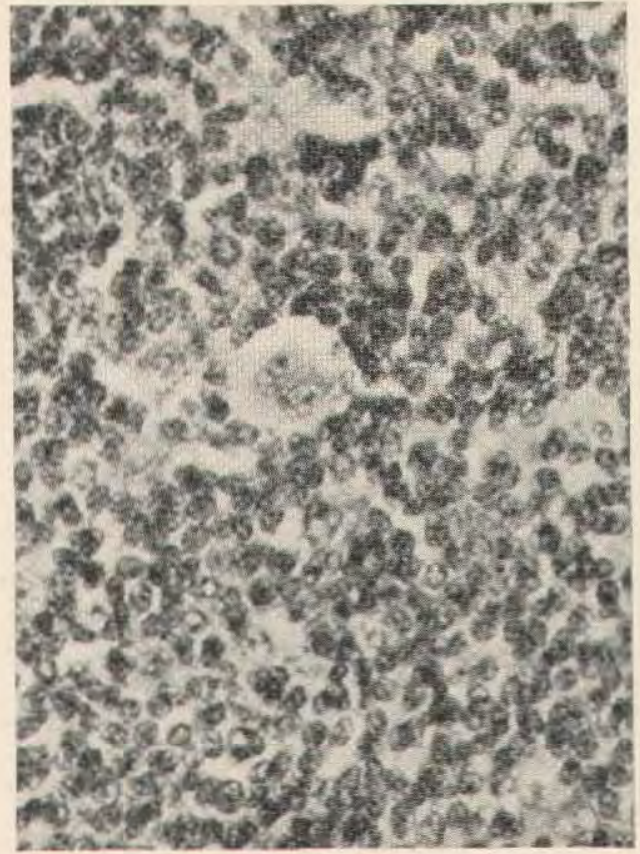

Fig. 2

Lymphocytic predominance. Almost all the cells are mature lymphocytes. A multinucleated ReedSternberg cell is in the centre (H and E, x400).

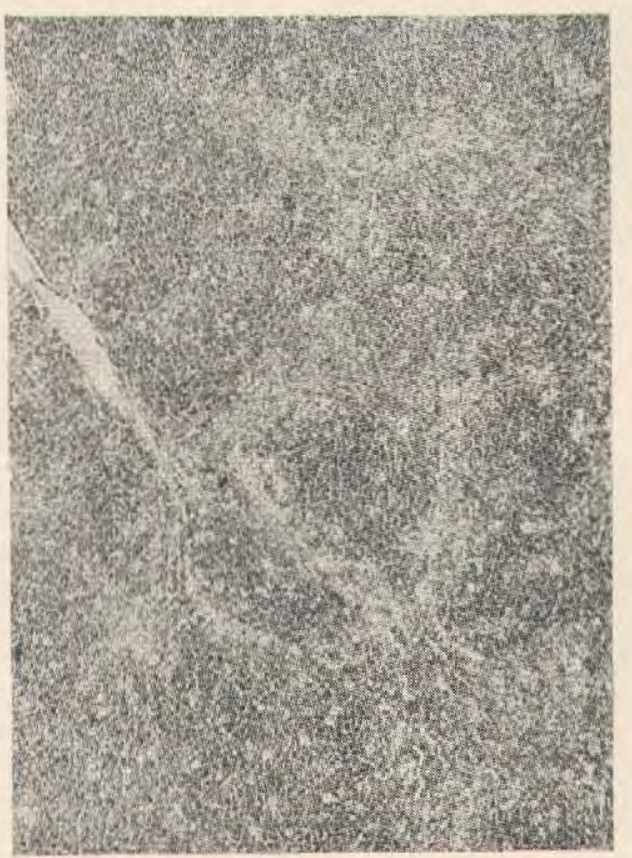

Fig. 4

Nodular sclerosis, cellular phase. Bands of collagen are slender and sparse in comparison to Fig. 3. Numerous lacunar cclls are evident ( $\mathrm{H}$ and $\mathrm{E} \times 25$ ).

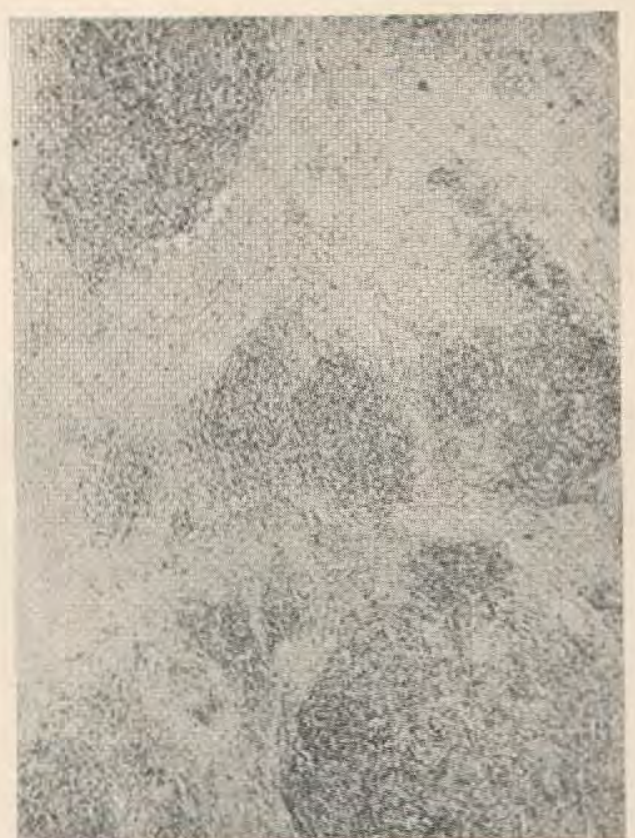

Fig. 3

Nodular sclerosis. Thick bands of collagen divide the lymph node into small cellular nodules $(\mathrm{H}$ and $\mathrm{E} \times 25$ ).

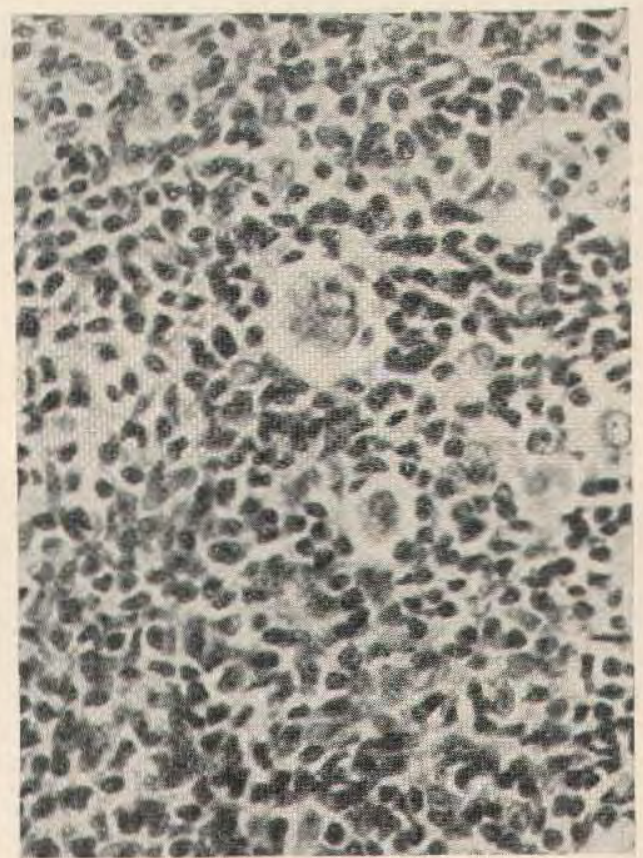

\section{Fig. 5}

Hodgkin's disease, nodular sclerosis. Several lacunar cells with hyperlobated nuclei are in the centre ( $\mathrm{H}$ and $\mathrm{E} \times 400)$. 


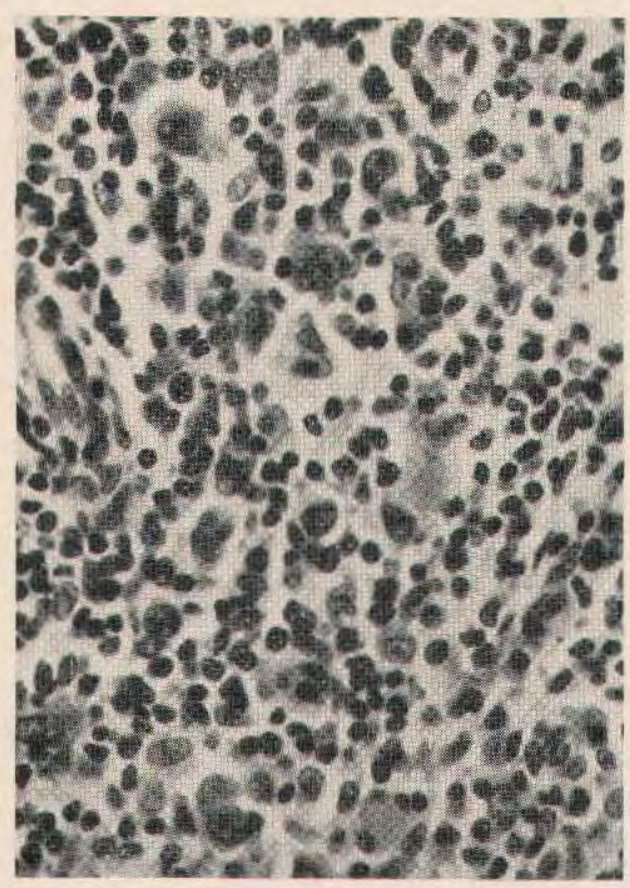

Fig, 6

Mixed cellularity. A mixture of numerous atypical reticulum cells, lymphocytes, histiocytes, cosinophils and plasma cells are seen ( $\mathrm{H}$ and $\mathrm{E}, \mathrm{x} 400)$.

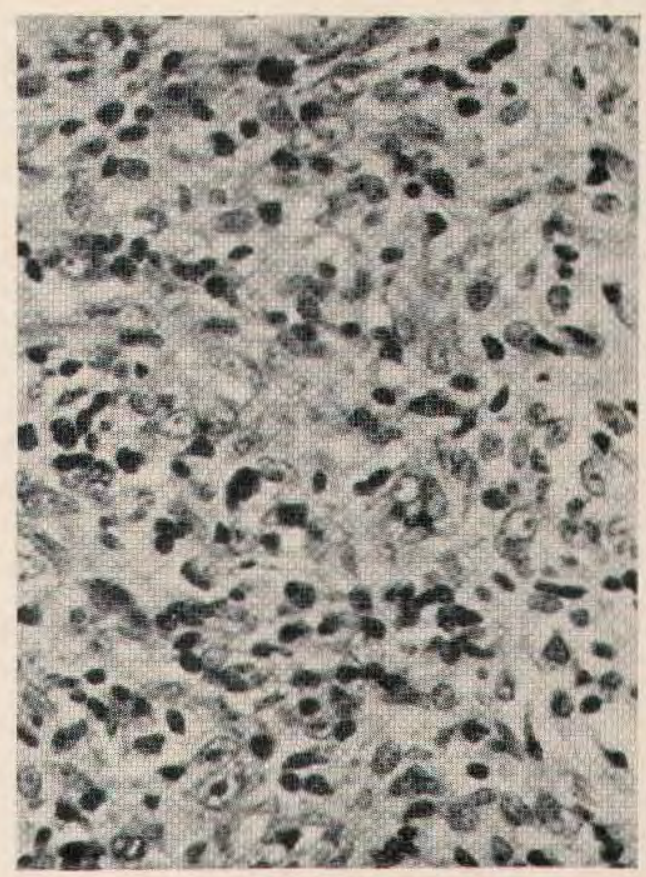

Fig. 7

Lymphocytic depletion. There is diffuse fibrosis with hypocellularity. The remaining cells are atypical reticulum cells. A Reed-Sternberg cell is present near the lower left corner ( $H$ and $E, x 400)$.

a lymph node shows nodular sclerosis and the remainder shows another group, the diagnosis of nodular sclerosis should take precedence.

Nodular sclerosis. The division of the lymph node into nodules by dense fibrous bands is considered the cardinal feature of nodular sclerosis (Lukes and Butler 1966a). An additional feature in most cases is the presence of lacunar cells. Lacunar cells are multi-nucleated reticulum cells usually with less prominent nucleoli than Reed-Sternberg cells and abundant pale cytoplasm which may have retracted in fixation creating the impression of a clear space or lacuna (Fig. 5). Kadin, Glatstein and Dorfman (1971) and Strum and Rappaport (1971a) believe that the diagnosis of nodular sclerosis can be suggested by the finding of lacunar cells even in the absence of collagenous bands. Strum and Rappaport (1971a) found that in 5 out of 7 cases in which an initial biopsy showed only this cellular phase of nodular sclerosis, subsequent biopsy revealed typical birefringent bands. The cellular phase of nodular sclerosis was shown by Kadin, Glatstein and Dorfman (1971) to have twice the risk of abdominal involvement as compared to biopsies having the typical broad collagenous bands.

In view of its good prognosis the separation of nodular sclerosis from the granuloma group of Jackson and Parker (1944) is perhaps the most significant contribution of the Rye classification. Nodular sclerosis differs from the other types of Hodgkin's disease in the consistency of histological pattern with disease progression (Strum and Rappaport 1971a) and in the more frequent occurrence in women and the younger age groups (Keller et al 1968). The male to female ratio for all types of Hodgkin's disease ranges in 
different studies between 1.5 and $1.2: 1$, but it is between 1.1 and $0.8: 1$ for nodular sclerosis (Keller et at 1968, Kadin, Glatstein and Dorfman 1971, Patchevsky et at 1973). In the study at AHR since most of the cases were from servicemen the overall sex ratio of $3.3: 1$ is not representative of the general population. Nonetheless, an increased proportion of females with nodular sclerosis was demonstrated by a lowering of the ratio for the group with nodular sclerosis to 2.9: 1 (Table III).

Table III

Sex distribution of 90 untreated patients related to histologic type in this series, 1965-1973

\begin{tabular}{l|r|r|r|r|r}
\hline \multirow{2}{*}{ Histologic type } & \multicolumn{2}{|c|}{ Males } & \multicolumn{2}{c|}{$\begin{array}{c}\text { Male : Female } \\
\text { ratio }\end{array}$} \\
\cline { 2 - 5 } & No & Per cent & No & Per cent & \\
Lymphocyte predominance & 4 & 6 & 1 & 5 & $4.0: 1$ \\
Nodular sclerosis & 35 & 51 & 12 & 57 & $3.9: 1$ \\
Mixed cellularity & 27 & 39 & 7 & 33 & $3.0: 1$ \\
Lymphocyte depletion & 3 & 4 & 1 & 5 & $3.3: 1$ \\
\hline Totals & 69 & 100 & 21 & 100 & 3 \\
\hline
\end{tabular}

A high incidence of mediastinal involvement lead to nodular sclerosing Hodgkin's disease being considered a regional expression of Hodgkin's disease (Lukes and Butler 1966a). Doubt has been cast on this concept by Kadin, Glatstein and Dorfman (1971) who noted a consistency of histological pattern in multiple sites and a 32 per cent incidence of abdominal involvement in previously untreated patients and by Patchevsky et al (1973) who observed that in clinical Stages I and II mixed cellularity involved the mediastinum more frequently than nodular sclerosis.

Case distribution. Table IV shows the distribution of cases according to histologic

Table IV

Distribution of 90 untreated patients according to histologic type in this series, 1965-1973

\begin{tabular}{|c|c|c|c|c|c|c|}
\hline \multirow[b]{2}{*}{ Histological type } & \multicolumn{2}{|c|}{ Entire study } & \multicolumn{2}{|c|}{ U.K. cases } & \multicolumn{2}{|c|}{ Non U.K. cases* } \\
\hline & No & Per cent & No & Per cent & No & Per cent \\
\hline Lymphocyte predominance & 5 & 6 & 3 & 4 & 2 & 9 \\
\hline Nodular sclerosis & 47 & 52 & 37 & 54 & 10 & 48 \\
\hline Mixed cellularity & 34 & 38 & 26 & 38 & 8 & 38 \\
\hline Lymphocyte depletion & 4 & 4 & 3 & 4 & 1 & 5 \\
\hline Totals & 90 & 100 & $69 \dagger$ & 100 & $21 \dagger$ & 100 \\
\hline
\end{tabular}

* Includes 7 patients from Africa, 5 from Nepal, 5 from Malaysia, 3 from Cyprus and 1 from Hong Kong.

† The numerical similarity between the comparison of sex distribution in Table III with distribution at home and overseas is purely coincidental.

type in biopsies from 90 untreated patients submitted to the Army Histopathology Registry between 1965 and 1973 and independently reviewed by the authors. This study included 69 patients from the United Kingdom, 7 from Africa, 5 from Nepal, 5 from Malaysia, 3 from Cyprus and 1 from Hong Kong. In Table V is presented the 
Table V

Distribution of cases according to histological types in ten series

\begin{tabular}{l|c|l|c|c|c|c}
\hline \multicolumn{1}{c|}{ Series } & Cases & Country & $\begin{array}{c}\text { Lymphocyte } \\
\text { predominance } \\
\text { (Per cent) }\end{array}$ & $\begin{array}{c}\text { Nodular } \\
\text { sclerosis } \\
\text { (Per cent) }\end{array}$ & $\begin{array}{c}\text { Mixed } \\
\text { cellularity } \\
\text { (Per cent) }\end{array}$ & $\begin{array}{c}\text { Lymphocyte } \\
\text { depletion } \\
\text { (Per cent) }\end{array}$ \\
\hline Lukes et al (1966b) & 377 & U.S.A. & 16 & 40 & 26 & 18 \\
\hline Franssila et al (1967) & 97 & Finland & 9 & 47 & 33 & 11 \\
\hline Keller et al (1968) & 176 & U.S.A. & $5+$ & 52 & 37 & 6 \\
\hline Gough (1970) & 96 & U.K. & 20 & 15 & 29 & 36 \\
\hline Kadin et al (1967) & 117 & U.S.A. & 11 & $73^{*}$ & $16 \dagger$ & $0 \dagger$ \\
\hline Olweny et al (1971) & 118 & Uganda & 7 & $8 *$ & $47^{\star}$ & $38^{\star}$ \\
\hline Teillet et al (1971) & 302 & France & 27 & 31 & 32 & 10 \\
\hline Selzer et al (1972) & 122 & S.Africa & 14 & 26 & 35 & 25 \\
\hline Newton et al (1973) & 250 & U.K. & $29^{*}$ & 31 & 24 & 16 \\
\hline Patchvesky et al (1973) & 235 & U.S.A. & 11 & 37 & 42 & 11 \\
\hline
\end{tabular}

* Highest percentage for histologic type. $\dagger$ Lowest percentage for histologic type.

incidence of the histologic groups of the Rye classification in ten studies from various countries. A composite of these series and the Army Histopathology study appears in Table VI. On comparing these series presented in Tables IV and V one is impressed

Table VI

Distribution of cases according to histologic type, composite of eleven series

\begin{tabular}{l|c|c}
\hline \multicolumn{1}{c|}{ Histologic type } & Number & Per cent \\
\hline Lymphocyte predominance & 320 & 16 \\
Nodular sclerosis & 729 & 37 \\
Mixed cellularity & 633 & 32 \\
Lymphocyte depletion & 298 & 15 \\
\hline Totals & 1980 & 100 \\
\hline
\end{tabular}

by their variability, the cause of which is not readily apparent except in those cases in which there are obvious selectivity factors such as extreme male predominance due to a military population in the Army Histopathology Registry study and the study of Lukes et al (1966), the exclusion of advanced cases by Kadin, Glatstein and Dorfman (1971) and, perhaps, a disproportionate number of advanced cases because of delay in presentation in the study of Olweny et al (1971).

A portion of the disparity in distribution could be due to an actual difference in the virulence or pathogenicity of the disease in various geographical locations or to a genetically determined or an acquired divergence in host responsiveness among populations. However, an important contributing factor and one that has a direct 
influence on correlations of histology with survival is observer disagreement. Complete accordance between three experienced pathologists on histological type was found in 67 per cent and 54 per cent of biopsies in the series of Keller et al (1968) and of Coppleson et al (1970), respectively. Correa et al (1973) found a 72 per cent agreement among pathologists from several countries which improved to 78 per cent on a second reading after a discussion of specific criteria. In a study in which the observers reviewed slides that they had previously diagnosed there was only 72 per cent unanimity (Coppleson et al 1970). Somewhat better results were described by Patchevsky et al (1973) who observed that on re-examination of material by a single histopathologist there was an 88 per cent consistency and by Kadin, Glatstein and Dorfman (1971) who found a 94 per cent correlation between two histopathologists examining the same cases. In the present material the authors initially agreed on 88 per cent of cases and interestingly there was minimal variation in the incidence of histological types between the group of patients from the United Kingdom and the group from outside the United Kingdom (Table IV).

Relationship to Survival. The ultimate determinant of the value of any histological classification is the extent to which it correlates with survival. A further study correlating the histological findings in the AHR material with the patients' clinical course and survival is planned. In view of differences in case selection, application of the histological classification and methods of treatment, it is difficult to compare series. However, most series do display a consistency in the ranking of histological type according to five-year survival (Table VII). Lymphocytic predominance usually has the best prog-

Table VII

Relationship of histologic type to five-year survival in different series (per cent)

\begin{tabular}{l|c|c|c|c}
\hline \multicolumn{1}{c|}{ Histologic type } & $\begin{array}{c}\text { Lukes et al } \\
(1966 \mathrm{~b})\end{array}$ & $\begin{array}{c}\text { Keller et al } \\
(1968)\end{array}$ & $\begin{array}{c}\text { Gough } \\
(1970)\end{array}$ & $\begin{array}{c}\text { Patchevsky } \\
\text { et al (1973) }\end{array}$ \\
\hline Lymphocyte predominance & 73 & 88 & 58 & 60 \\
Nodular sclerosis & 44 & 71 & 45 & 65 \\
Mixed cellularity & 31 & 37 & 18 & 30 \\
Lymphocyte depletion & 13 & 38 & 8 & 10 \\
\hline Totals & 40 & 57 & 26 & 40 \\
\hline
\end{tabular}

nosis, closely followed by nodular sclerosis. These two groups have a distinctly better prognosis than mixed cellularity and lymphocytic depletion. Females under 30 have an increased survival because of a prevalence of nodular sclerosis (Keller et al 1968). Neiman, Rosen and Lukes (1973) consider lymphocytic depletion a distinct clinicopathological entity consisting of rapidly fatal disease, fever, pancytopenia, extensive involvement of the liver, spleen, retroperitoneal lymph nodes and bone marrow with absent or slight peripheral lymphadenopathy. The presence of vascular invasion (Fig. 8) in the lymph nodes or the spleen is associated with extranodal organ involvement and is an indicator of extensive involvement even when the disease belongs to one of the generally more favourable histological types (Rappaport et al 1971a). 


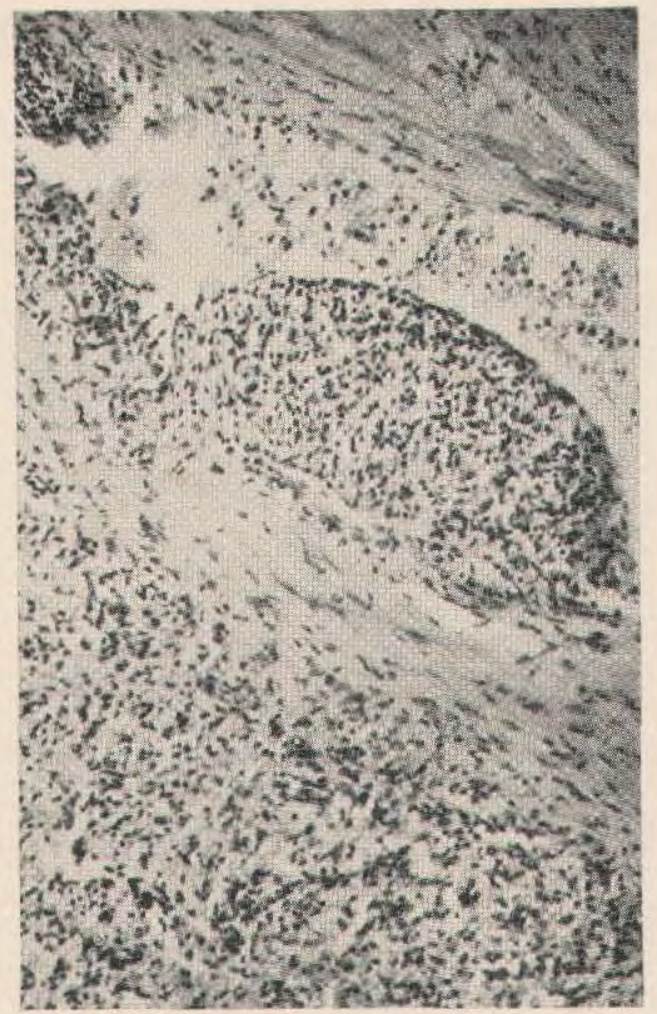

Fig. 8

Vascular invasion. A trabecular vessel in the spleen contains a tumour nodule which has damaged the intima ( $\mathrm{H}$ and $\mathrm{E}, \mathrm{x} 100)$.

\section{Staging}

Classification. The extent of disease at onset serves as a valuable prognostic parameter and as a therapeutic guide. The first practical method of clinical staging was devised by Peters (1950). An improved staging classification was introduced at an International Symposium on Hodgkin's disease at Rye, New York in 1965 to separate generalised lymphadenopathy (Stage III) from disease involving extralymphatic tissues or organs (Stage IV) (Rosenberg 1966). Musshoff (1971) observed that patients with extranodal tissue or organ involvement in direct continuity with involved lymph nodes carried a significantly better prognosis than would be expected from Stage IV disease. Therefore, at the Ann Arbor, Michigan Symposium on the Staging of Hodgkin's disease in 1971 it was proposed that within each stage there be a category for contiguous extranodal involvement designated by a subscript letter E (Carbone et al 1971) (Table VIII). All stages of this classification are further subdivided into the absence (A) or presence (B) of general symptoms. General symptoms are unexplained weight loss of more than ten per cent of body weight in the six months prior to admission, unexplained fever with temperature above $30^{\circ} \mathrm{C}$ and night sweats. The presence of pruritus alone is no longer thought to justify sub-classification B (Carbone et al 1971).

Halie, Eibergen and Nieweg (1972a) found in a study of peripheral blood leucocyte concentrates that patients with disease in the spleen have a high incidence of abnormal large blast-like cells in the peripheral blood. This was interpreted as supporting haematogenous spread or multicentric origin. Based on this finding and the poor results of treat- 
Table VIII

Ann Arbor clinical staging classification (Carbone et al 1971)

\begin{tabular}{c|l}
\hline Stage & \multicolumn{1}{c}{ Description } \\
\hline I & $\begin{array}{l}\text { Involvement of a single lymph node region (I) or of a single extralymphatic organ or } \\
\text { site (I-E) }\end{array}$ \\
\hline II & $\begin{array}{l}\text { Involvement of two or more lymph node regions on the same side of the diaphragm } \\
\text { (II) or localised involvement of an extralymphatic organ or site and of one or more } \\
\text { lymph node regions on the same side of the diaphragm (II-E) }\end{array}$ \\
\hline III & $\begin{array}{l}\text { Involvement of lymph node regions on both sides of the diaphragm (III), which may } \\
\text { also be accompanied by involvement of the spleen (III-S) or by localised involvement } \\
\text { of an extralymphatic organ or site (III-E) or both (III-SE) }\end{array}$ \\
\hline IV & $\begin{array}{l}\text { Diffuse or disseminated involvement of one or more extralymphatic organs or tissues } \\
\text { with or without associated lymph node involvement }\end{array}$ \\
\hline
\end{tabular}

ment that they obtained when the spleen was involved, Halie et al (1972b) proposed a staging classification in which the extent of disease was described as "localised " when confined to the lymph nodes and as "disseminated" when the spleen or other organs or both were involved.

Diagnosis. Procedures recommended by the Committee on the Staging of Hodgkin's disease at the Rye conference (Rosenberg 1966) included careful history, complete physical examination, full blood count, platelet count, erythrocyte sedimentation rate, chest film with tomograms for hilar adenopathy, skeletal survey, excretory urogram, lymphangiography, liver and renal function tests. These procedures did not prove sufficiently accurate and, consequently, a more aggressive approach consisting of laparotomy with splenectomy and biopsies of the liver and abdominal lymph nodes was advocated (Glastein et al 1969). Marston (1972) found that after a complete clinical investigation the staging of the disease was altered in two thirds of his patients. Half of the patients had splenic involvement despite negative clinical examination and scanning and 24 per cent had disease in the lymph nodes that was not evident by lymphangiography.

Splenectomy. Besides augmentation of the accuracy of staging, splenectomy results in an improved haematological tolerance to radiotherapy (Salzman and Kaplan 1971) and to chemotherapy (Lowenbraun, Ramsey and Serpick 1971) as well as allowing irradiation of the nodes along the splenic pedicle without damage to the left lower lobe of the lung and the left kidney (Glastein et al 1969). Against these advantages must be balanced the disadvantages in terms of morbidity, mortality and possible detrimental effects to the patient's immunological defences. It has been recommended that exploratory laparotomy and splenectomy be performed only if therapeutic decisions will depend on the findings (Rosenberg et al 1971).

Pathological Aspects. Kadin, Glatstein and Dorfman (1971) and Farrer-Brown et al (1972) found no absolute correlation between the size and weight of the spleen and involvement of the organ. Spleens weighing up to 690 grams may be free of tumour while those weighing less than 100 grams may be involved. Since foci of Hodgkin's disease may be minute and difficult to detect, Farrer-Brown et al (1972) recommended slicing through the organ at 2-3 mm. Disease in the liver was not detected in the absence 
of disease in the spleen (Kladin, Glatstein and Dorfman (1971). Essentially due to the small size of the specimens the rigid criteria mandatory for the diagnosis of Hodgkin's disease in the lymphoid tissue are relaxed in the liver and the bone marrow in previously diagnosed cases to the extent that Hodgkin's disease is considered likely to be present if atypical reticulum cells are found in an appropriate cellular milieu (Rappaport et al 1971b). The significance of isolated sarcoid-like granulomas in 14 per cent of tissues from patients with Hodgkin's disease is not known, but they are not considered to represent involvement by Hodgkin's disease, sarcoidosis or granulomatous infectious disease (Kadin, Glatstein and Dorfman 1971).

Primary Extranodal Hodgkin's Disease. In contrast to the other lymphomas Hodgkin's disease rarely occurs as a primary disease limited to an extranodal site. Wood and Coltman (1973) estimated that the incidence of this form was one quarter of one percent of the overall incidence of Hodgkin's disease. They noted an excellent prognosis for cases arising in the skin, tongue, lung, stomach, small bowel and thyroid, but doubted that cases in areas such as the central nervous system and kidney would have the excellent prognosis connoted by Stage $1 \mathrm{E}$ disease.

\section{Treatment}

The principal modalities in the current therapeutic armamentarium are megavoltage radiation therapy and combination chemotherapy. Their utilization varies considerably among specialist centres. At Stanford University total lymphoid irradiation is the treatment for Stages I, II and III (Rosenberg and Kaplan 1970). At the Royal Marsden Hospital female patients with lymphocytic predominance or nodular sclerosis in Stage I A are treated by the mantle technique without undergoing laparotomy. All other Stage I, II and III A patients undergo laparotomy. Supradiaphragmatic Stage I and II are treated by the mantle technique with a paraaortic strip, while infradiaphragmatic Stage I and II receive an inverted $Y$ with inclusion of the splenic axis if the spleen is involved. Total lymphoid irradiation is reserved for Stage III A and combination therapy for III B (Peckham 1973). Both centres use combination chemotherapy for Stage IV.

De Vita, Canellos and Moxley (1972) at the National Cancer Institute treat patients in Stages III and IV with a combination administered in monthly cycles of vincristine sulfate, nitrogen mustard (or cyclophosphamide), procarbazine hydrochloride and prednisone (MOPP). He has found this regime superior to single agent therapy or to the same agents used one at a time. Rosenberg et al (1972) compared the results of treatment with total lymphoid irradiation alone to total lymphoid irradiation followed by six cycles of combination therapy with MOPP for Stages I B to III B. Although there were fewer relapses in the latter group the authors did not consider that the results warranted a recommendation for sequential radiation therapy and chemotherapy.

\section{Prognosis}

Patients with Stage I or II disease carefully staged and treated with total lymphoid megavoltage radiotherapy can expect a relapse-free survival at five years of 85-90 per cent (Kaplan 1970). Johnson, Glover and Marshall (1971) report a five year survival of 98 per cent and 76 per cent for Stages I-II A and B, respectively, and 70 per cent for 
Stage III A. Rosenberg et al (1972) obtained a four year disease-free survival of almost 90 per cent for Stages I B to III B treated with sequential radiotherapy and irradiation. Even in advanced Hodgkin's disease encouraging results have been attained. De Vita, Canellos and Moxley (1972) report for Stage III and IV disease a survival in excess of 60 per cent at 6 years. These most promising results must be tempered somewhat by the finding at post-mortem examination of evidence of Hodgkin's disease in sixteen of eighteen patients who had survived more than ten years (Strum and Rappaport 1971b). Strum and Rappaport (1971b) suggested that in some patients with Hodgkin's disease apparent clinical cure may represent "a state of equilibrium in which the host has come to terms with his disease." By current standards, however, these patients had not received adequate therapy. We must await the results of necropsy studies on optimally treated patients with lengthy survivals to ascertain the likelihood of complete cure. Also disturbing are reports of Hodgkin's disease terminating in acute leukaemia (Osta et al 1970) or in widespread metastatic disease from a second malignant tumour, especially after both intensive radiotherapy and intensive chemotherapy (Arseneau et al 1972).

Overall, however, the prognosis for survival in patients with Hodgkin's disease is now excellent, particularly with localised disease, and represents the combined efforts of many specialists including physicians, surgeons, radiotherapists, oncologists, immunologists and pathologists. Continued close co-operation between the various branches of clinical and experimental medicine is necessary for maximal patient care and ultimately for a way out of " the maze".

\section{REFERENCES}

AISENBERG, A: C. (1962). J. clin. Invest. 41, 1964.

AisenberG, A. C. (1966). Cancer (Philad.) 19, 385.

Arseneau, J. C., Sponzo, R. W., Levin, D. L., Schnipper, L. E., Bonner, H., Young, R. C., Canel los, G. P., Johnson, R. E. and DeVita, V. T. (1972). New Engl. J. Med. 287, 1119.

Bertrams, J., Kuwert, E., Böhme, U., Reis, H. E., Gallmeier, W. M., Welter, O. and Schmidt, C. G. (1972). Tissue Antigens 2, 41 .

Brown, R. S., Haynes, W. A., Foley, H. T., Godwin, H. A., Berard, C. W. and Carbone, P. P. (1967). Ann intern. Med. 67, 291.

BurkitT, D. P. (1969). J. nat. Cancer Inst. 42, 19.

Carbone, P. P., Kaplan, H. S., Musshoff, K., Smithers, D. W. and Tubiana, M. (1971). Cancer Res. 31, 1860 .

Cole, P., Macmahon, B. and Aisenberg, A. (1968). Lancet ii, 1371.

Coppleson, L. W., Factor, R. M., Strum, S. B., Graff, P. W. and Rappaport, H. (1970). J. nat. Cancer Inst. 45, 731.

Correa, P., O’Conor, G. T., Berard, C. W., Axtell, L. M. and Meyers, M. H. (1973). J. nat. Cancer Inst. 50, 1429.

Cross, R. M. (1969). J. clin. Path. 22, 165.

DeVita, V. T., Canellos, G. P. and Moxlex, J. H. III (1972). Cancer (Philad.) $30,1495$. DeVita V. T. (1973). New Engl. J. Med. 289, 801.

Eisinger, M., Fox., S. M., DeHarven, E., Bredier, J. L. and Sanders, F. K. (1971). Nature (Lond.) 233, 104 .

Epstein, M. A., Achong, B. G. and Barr, Y. M. (1964). Lancet i, 702.

Farrer-Brown, G., Bennett, M. H., Harrison, C. V., Millet, Y. and Jelliffe, A. M., (1972). J. clin. Path. 25, 294.

Forbes, J. F. and Morris, P. J. (1970). Lancet ii, 849.

Franssila, K. O., Kalma, T. V. and Voutilainen, A. (1967). Cancer (Philad.) $20,1594$.

Glatstein, E., Guernsey, J. M., Rosenberg, S. A. and Kaplan, H. S. (1969). Cancer (Philad.) $24,709$.

Goldman, J. M. and Aisenberg, A. C. (1970). Cancer (Philad.) 26, 327.

Gough, J. (1970). Int. Cancer 5, 273.

Halie, M. R., Eibergen, R. and Nieweg, H. O. (1972a). Brit. med. J. ii, 609.

Halie, M. R., Seldenrath, J. K., Stam, H. C. and Nieweg, H. O. (1972b). Brit. med. J. ii, 611.

HARTSOCK, R. J. (1968). Cancer (Philad.) 21, 632. 
Hersh, E. M. and Oppenheim, J. J. (1965). New Engl. J. Med. 273, 1006.

HodGKIN, T. (1832). Med.-chir. Trans 17, 68. In Proc. roy. Soc. Med.

JACKSON, H. and PARKer, F. (1944). New Engl. J. Med. $230,1$.

Johansson, B., Klein, G., Henle, W. and Henle, G. (1970). Int. J. Cancer 6, 450.

Johnson, R. E., Glover, M. K. and Marshall, S. K. (1971). Cancer Res. 31, 1834.

JoHnSON, S. K. and JoHnSON, R. E. (1972). New Engl. J. Med. 287. 1122.

Kadin, M. E., Glatstein, E. and Dorfman, R. F. (1971). Cancer (Philad.) 27, 1227.

Kaplan, H. S. (1970). Harvey Lect. 1968-1969. Series 64, 215. C.C. Thomas. Illinois.

Kaplan, H. S. (1971). Brit. J. Cancer 25, 620.

Keller, A. R., Kaplan, H. S., Lukes, R. J. and RapPaport, H. (1968). Cancer (Philad.) $22,487$.

LANCET EDITORIAL (1969). ii, 728.

LANCET EDITORIAL (1971). i, 1053.

Levine, P. H., Ablashi, D. V., Berard, C. W., Carbone, P. P., Waggoner, D. E. and Malan, L. (1971) Cancer (Philad.) 27, 416 .

LILly, F., BoySe, E. A. and OLd, L. J. (1964). Lancet ii, 1207.

Longmire, R. L., McMillan, R., Yelenosky, R., Armstrong, S., Lang, J. E. and Craddock, C. G. (1973). New Engl. J. Med. 289, 763.

Lowenbraun, S., Ramsey, H. E. and Serpick, A. A. (1971). Amer. J. Med. 50, 49

LUKES, R. J. and BUTLER, J. J. (1966a). Cancer Res. 26, 1063.

LuKes, R. J., Butl.er, J. J. and HiCKs, E. B. (1966b). Cancer (Philad.) 19, 317.

Lukes, R. J., Craver, L. F., Hall, T. C., Rappaport, H. and Rueben, P. (1966c). Cancer Res. $26,1311$.

Lukes, R. J., Tindle, B. H. and Parker, J. W. (1969). Lancet ii, 1003.

MacMahon, B. (1957). Cancer (Philad.) 10, 1045.

MacMahon, B. (1966). Cancer Res. 26, 1189.

Marston, A. (1972). Proc. roy. Soc. Med. 65, 1111.

Martin, W. T., Ellman, L. Green, I. and Benacerraf, B. (1970). J. exp. Med. 132, 1259.

Miller, D. G., Lizardo, J. G. and Snyderman, R. K. (1961). J. nat. Cancer Inst. $26,569$.

Musshoff, K. (1971). Cancer Res. 31, 1814.

Neiman, R. S., Rosen, P. J. and Lukes, R. J. (1973). New. Engl. J. Med. 288, 751.

Newell, G. R., Cole, S. R., Miettinen, O. S. and MacMahon, B. (1970).. J. nat. Cancer Inst. $45,311$.

Newton, K. A:, Mackenzie, D. H., SpitTle, M. F. and Mikolajczuk, A. (1973). Brit. J. Cancer 27, 80

Niederman, J. C., McCollum, R. W., Henle, G. and Henle, W. J. (1968). J. Amer. med. Ass. $203,205$.

Olweny, C. L. M., Ziegler, J. L., Berard, C. W. and Templeton, A. C. (1971). Cancer (Philad.) 27, 1295.

Order, S. E. and Hellman, S. (1972). Lancet i, 571.

Osta, S., Wells, M., Viamonte, M. and Harkness, D. (1970). Cancer (Philad.) 26, 795.

Patchevsky, A. S., Brodovsky, H., Southard, M., Menduke, H., Gray, S. and Hoch, W. S. (1973). Cancer (Philad.) 32, 150.

Peckman, M. J. (1973). Hosp. Med. 9, 457.

Peters, M. V. (1950). Amer. J. Roentgenol. 63, 299.

Piperno, J. R. and Kallen, R. G. (1973). Cancer Res. 33, 838.

Rappaport, H., Strum, S. B., Hutchison, G. and Allen, L. W. (1971a). Cancer Res, $31,1794$.

Rappaport, H., Berard, C. W., Butler, J. J., Dorfman, R. F. Lukes, R. J. and Thomas, L. B. (1971b). Cancer Res. 31, 1864

RosEnBERG, S. A. (1966). Cancer Res. 26, 1310.

Rosenberg, S. A. and Kaplan, H. S. (1970). Calif. Med. 113, 23.

Rosenberg, S. A., Botron, M., DeVita, V. T., Johnson, R. E., Lee, B. J., UltmanN, T. E. and Viamonte, M. (1971). Cancer Res. 31, 1862.

Rosenberg, S. A., Moore, M. R., Bull, J. M., Jones, S. E. and Kaplan, H. S. (1972). Cancer (Philad.) 30, 1505 .

RuUSKanen, C., Vanha-perttula, T, and Kouvalainen, K. (1971). Lancet i, 1127.

Salzman, J. R. and Kaplan, H. S. (1971). Cancer (Philad.) 27, 471.

Scheir, W. W., Roth, A., Ostroff, G. and Schrift, M. (1956). Amer. J. Med. $20,94$.

SCHNITZER, B. (1970). Lancet i, 1399.

Schwartz, R. S. and Andre-Schwartz, J. (1968). Ann. Rev. Med. 19, 269.

Selzer, G., Kahn, L. B. and Sealy, R. (1972). Cancer (Philad.) 29, 1090.

SMITHERS, D. W. (1970). Lancet ii, 1285.

Strum, S. B., Park, J. K. and Rappaport, H. (1970). Cancer (Philad.) 26, 176.

Strum, S. B. and RapPaport, H. (1971a). Arch. Path. 91, 127.

Strum, S. B. and RAPPAPORT, H. (1971b). Amer. J. Med. 51, 222.

Symmers, W. St. C. (1968). J. clin. Path. 21, 650.

Teillet, F., Boiron, M. and Bernard, J. (1971). Cancer Res. 31, 1723.

Vianna, N. J. and Polan, A. K. (1973). New Engl. J. Med. 289, 499.

Vianna, N. J., Greenwald, P. and Davies, J. N.P. (1971). Lancet. i, 431.

Vianna, N. J., Greenwald, R., Brady, J., Polan, A. K., Dwork, A., Mauro, J. and Davies, J. N. P. (1972). Ann. intern. Med. 77, 169.

Young, R. C., Corder, M. P., HAynes, H. A. and DeVita, V. T. (1972). Amer. J. Med. 52,63

Wood, N. L. and Coltman, C. A. (1973). Ann. intern. Med. 78, 113.

Wright, D. H. (1970). Lancet i, 1052. 